\title{
Peranan Bimbingan Kelompok Dalam Meningkatkan Ketaatan Siswa Terhadap Tata Tertib Sekolah Pada Siswa Kelas IX SMP Negeri 1 Rogojampi Banyuwangi Tahun Pelajaran 2015/2016
}

\author{
Sri Surachmi \\ Dosen Program Bimbingan dan Konseling, Universitas PGRI Banyuwangi \\ Jln. Kalimantan 37, Jember 68121 \\ E-mail: srisurachmi@gmail.com
}

\begin{abstract}
Abstrak
Penelitian ini bertujuan untuk mengetahui dan menganalisis (1) dapat tidaknya layanan bimbingan kelompok meningkatkan ketaatan peserta didik terhadap tata tertib sekolah, dan (2) peningkatkan disiplin peserta didik terhadap tata tertib sekolah. Subjek penelitian ini adalah siswa kelas IX SMP 1 Rogojampi, Banyuwangi,Semester 1, Tahun Pelajaran 2015/2016. yang melakukan pelanggaran terhadap tata tertib sekolah pada bidang pakaian seragam, kehadiran di sekolah, dan pembayaran Sumbangan Komite Sekolah. Dalam penelitian ini, siswa menjadi sumber utama dalam perolehan data berkaitan dengan pelanggaran terhadap tata tertib sekolah pada bidang pakaian seragam, kehadiran di sekolah, dan pembayaran Sumbangan Komite Sekolah pada siswa kelas IX SMP 1 Rogojampi. Alasan mengapa penelitian ini dilaksana-kan di kelas IX atau dijadikan subjek penelitian karena adanya permasalahan-permasalahan diantaranya: pelanggaran terhadap tata tertib sekolah pada bidang pakaian seragam, kehadiran di sekolah, dan pembayaran Sumbangan Komite Sekolah masih cukup tinggi. Rancangan penelitian tindakan bimbingan dan konseling (PTBK) ini diambil menurut Kemmis dan McTaggrat yang memberikan batasan pelaksanaan, yakni : (1).Tahap Perencanaan, (2).Tahap Tindakan, (3).Tahap Observasi/ Evaluasi, (4).Tahap Terakhir adalah Refleksi. Sedangkan Teknik analisis yang digunakan untuk mengolah data di atas adalah : Analisis Varians (Anava). Berdasarkan hasil perhitungan nilai F dan uji t Scheffe menunjukkan signifikan, yang berarti Ho ditolak, maka dengan demikian dapat ditarik kesimpulan bahwa: (1) Layanan Bimbingan kelompok dapat meningkatkan ketaatan siswa terhadap tata tertib sekolah, dan (2) Layanan Bimbingan kelompok dapat meningkatkan disiplin siswa. pada Siswa Kelas IX SMP Negeri 1 Rogojampi, Banyuwangi,Semester 1, Tahun Pelajaran 2015/2016. Kepada Wali Kelas, guru mata pelajaran, guru pembimbing dan staf sekolah lainnya apabila menemukan siswa yang melakukan pelanggaran terhadap tata tertib sekolah hendaknya sedini mungkin menanganinya dengan cara memberikan layanan bimbingan kelompok karena bimbingan kelompok merupakan salah satu cara yang sudah terbukti dapat meningkatkan ketaatan siswa terhadap tata tertib sekolah.
\end{abstract}

Kata Kunci: Ketaatan terhadap tata tertib sekolah, bimbingan kelompok.

\section{Pendahuluan}

Masyarakat dunia sedang memasuki zaman informasi. Bangsa-bangsa yang belum maju ada dorongan untuk mengejar ketertinggalannya se-hingga dalam waktu sesingkat-singkat-nya dapat ikut serta memasuki zaman informasi pada awal abad ke-21. Zaman informasi telah melanda seluruh dunia sehingga masyarakat dunia seakan-akan "menjadi satu" dan terciptalah era globalisasi.

Globalisasi dan informasi ibarat dua sisi dari satu mata uang. Perkembangan yang semakin deras arus informasi melalui media massa merupakan senjata yang paling ampuh bagi berlangsungnya proses globalisasi, sedangkan semangat globa-lisasi itu sendiri membuka pintu dan salur-an yang seluas-luasnya bagi masuknya informasi dari dan ke seluruh penjuru dan pelosok dunia. Dengan semangat globa-lisasi yang semakin meningkat melalui arus informasi yang semakin menggebu, ditunjang pula oleh kemajuan teknologi yang semakin canggih, seluruh bagian dunia sampai ke bagian yang paling jauh dan terpencil sekalipun menjadi terbuka, sehingga tidak ada lagi daerah yang tidak terjangkau oleh informasi dan tidak ada lagi daerah yang terisolir. Seluruh bagian dunia menjadi tembus pandang, membuka diri, dan siap untuk berubah.
Dalam menghadapi masa depan yang berubah, yang tidak dapat dielakkan itu, orang mungkin bersikap pesimistik ataupun optimistik. Mereka yang pesimistik ber-pandangan bahwa globalisasi dapat meng-goncang dan mengganggu keseimbangan masyarakat. Derasnya arus globalisasi itu akan meruntuhkan nilai-nilai moral dan sosial serta tatanan kemasyarakatan yang dianggap telah mapan di masyarakat dari generasi ke generasi. Hancurnya nilai-nilai moral dan sosial ini pada gilirannya akan menimbulkan ke-resahan dan kerusuhan di dalam masyarakat yang secara langsung berdampak negatif terhadap anggota masyarakat dalam skala yang tak ter-bayangkan. Masa depan yang demikian itu akan penuh dengan bahaya dan ke-munduran-kemunduran.

Ketaatan mengandung arti kepatuhan melaksanakan segala aturan/peraturan [1]. Sedangkan ketaatan yang dimaksud menurut Depdikbud [2], diartikan sebagai suatu kepatuhan atau kesetiaan terhadap atur-an/peraturan.Lebih lanjut sumber lain me-nyatakan bahwa yang dimaksud dengan ketaatan adalah mematuhi peraturan-peraturan, ketentuan-ketentuan, dan tata tertib yang berlaku di sekolah $[2]$.

Berdasarkan beberapa pendapat yang telah dikemukakan di atas dapat ditarik suatu pengertian bahwa ketaatan yang dimaksud pada penelitian ini adalah kepatuhan 
atau kesetiaan dalam melak-sanakan segala peraturan, ketentuan, dan tata tertib yang berlaku di sekolah. Tata Tertib Sekolah adalah ketentuan-ketentuan yang mengatur kehidupan seko-lah sehari-hari dan mengandung sangsi terhadap pelanggarannya [2]. berikut.

Ruang Lingkup Tata Tertib Sekolah mencakup sebagai

a) Kegiatan Sekolah

1) Siswa harus ada di sekolah 15 menit sebelum bel kegiatan sekolah pertama berbunyi.

2) Siswa baru boleh me-ninggalkan sekolah sete-lah semua pelajaran selesai atau setelah mendapat ijin dari Kepala Sekolah atau Guru Piket.

3) Pada hari Senin kegiatan sekolah pertama dimulai dengan Upacara Penaikan Bendera yang diikuti oleh segenap pelajar dan segenap personel sekolah.

4) Kalau kegiatan dilaksanakan di luar kelas, maka kelas harus dalam keadaan terkunci.

5) Waktu masuk kelas para siswa harus berbaris dengan tertib, dipimpin oleh ketua kelas.

6) Sebelum pelajaran pertama dimulai para siswa mengucapkan doa sesuai dengan agama dan kepercayaan masing-masing dipimpin oleh petugas.

7) Sebelum masing-masing pelajaran dimulai para siswa haru sudah siap menerima pelajaran sesuai dengan jadwal pelajaran.

8) Pada waktu tidak ada guru yang mengajar para siswa tetap tinggal di kelas dengan tenang sehingga tidak mengganggu kelas lain sampai ada ketentuan lebih lanjut

dari Kepala Sekolah/Guru Piket.

9) Pada waktu jam istirahat siswa tidak dibenarkan berada di 7) Sopan Santun dalam kelas.

10) Selama waktu sekolah, siswa tidak boleh meninggalkan sekolah tanpa ijin Kepala Sekolah/Guru Piket

11) Siswa tdak dibenarkan menjadi anggota organisasi di luar OSIS (Organisasi Siswa Intra Sekolah).

12) Siswa hanya boleh dan harus menjadi anggota OSIS

13) Setiap siswa mengikuti kegiatan ekstrakurikuler yang diadakan sekolah

14) Siswa tidak boleh mengendarai sepeda motor ke sekolah

15) Siswa tidak boleh merokok di dalam maupun di luar sekolah

16) Tidak boleh mengendarai sepeda diemper atau ha-laman sekolah.

b) Absen :

1) Siswa yang tidak hadir di sekolah karena sakit. Oleh orang tua/ walinya harus dimohonkan ijin tidak masuk secara tertulis. surat per-mohonan harus bersampul. Kalau tidak masuk lebih dari 2 hari harus disertai dengan keterangan dokter.

2) Siswa yang tidak masuk karena hal lain, misalnya kerja adat atau hal-hal lain yang sudah diketahui sebelumnya harus minta ijin secara lisan kepada Kepada Sekolah terlebih dhulu, setelah diijinkan barulah boleh tidak masuk dan membawa surat secara resmi.

c) Pakaian

1) Para siswa harus memiliki 3 stel pakaian seragam (bahannya dikelola oleh koperasi sekolah) a) 2 stel putih biru tua pakaiannya tiap-tiap hari, kecuali hari Jumat, Sabtu memakai pakaian atas batik dan bawah biru tua.

b) Seragam Pramuka (pakaiannya hari yang ditentukan)

2) Pakaian Olah Raga :

a) Untuk pria celana olah raga hijau

b) Untuk wanita profbroek hijau memakai elastik pada kakinya

c) Baju kaos putih

d) Sepatu olah raga

3) Sepatu

a) Sepatu sehari-hari berwarna hitam tidak memakai hal tinggi (plastik)

b) Kaos kaki putih

c) Tidak diperkenankan memakai sandal ke sekolah.

4) Blouse/Baju

a) Harus berleher dan bertangan pendek

b) Celana tidak terlalu pendek dan ketat

c) Rok tidak ketat dan panjang-nya $5 \mathrm{~cm}$ di bawah lutut

d) Blouse atau baju harus dimasukkan ke rok atau celana

Dandanan

a) Tidak diperkenankan menggunakan alat-alat seperti perhiasan lebih-lebih siswa pria

b) Dandanan tidak berlebihan tidak memakai alat-alat make up kecuali bedak

6) Rambut

a) Pria tidak boleh berambut gondrong

b) Wanita berambut panjang harus dijalin dengan rapi

a) Setiap sisva

wa harus kenal dan tahu nama semua staf

b) Para siswa harus memberi hormat kepada semua guru dan staf sekolah baik di sekolah maupun di luar sekolah

c) Para siswa memberi hormat bersama dalam keadaan berdiri (dengan dipimpin oleh ketua kelas) kepada setiap guru yang masuk untuk pertama kali pada kelasnya dan tidak boleh duduk sebelum guru menyuruh duduk atau sebelum guru itu duduk.

d) Para siswa harus memberi hormat oleh guru atau Kepala Sekolah

e) Para siswa harus mem-beri hormat kepada setiap tamu yang datang di sekolah dengan cara menyapa dan sebagainya dan siap memberikan pelayanan kalau diperlukan.

f) Para siswa harus selalu sopan dalam bersikap, berbicara, duduk bertingkah laku dan lain-lain (misalnya tidak sopan kalau berbicara dengan membelakangi orang yang diajak berbicara, memegang bangku atau meja pada waktu meng-hadap memasuki ruangan tanpa ijin atau tanpa permisi terlebih dahulu, makan sambil jalan, menguap tanpa menutup mulut)

8) Keuangan
a) Setiap siswa dikenakan uang :
b) Iuran Komite Sekolah perbulan
c) Iuran OSIS perbulan
d) Tabungan pelajar perbulan 
e) Pembayaran dilakukan paling lambat tanggal 10 bulan yang bersangkutan.

9) Kebersihan

Setiap siswa harus aktif menjaga dan memelihara kebersihan seko-lah dan lingkungan

a) Setiap pagi kelas (lantai, langit-langit, dinding) harus bersih dan rapi.

b) Sebelum guru mulai mengajar papan tulis harus bersih (tanpa tulis-an atau gambar-gambar)

10) Sangsi-sangsi

Bagi siswa yang melanggar tata tertib akan dikenakan sangsi-sangsi sebagai berikut :

a) Peringatan pertama secara langsung kepada siswa yang bersangkutan

b) Peringatan kedua langsung kepada siswa dan pemanggil-an orang tua/wali secara tertulis

c) Dirumahkan untuk sementara

d) Dikembalikan kepada orang tuanya

Layanan bimbingan kelompok yaitu layanan bimbingan yang memungkinkan sejumlah peserta didik secara bersamasama memperoleh berbagai bahan dari nara sumber tertentu (terutama dari pembimbing/konselor) yang berguna untuk menunjang kehidupannya sehari-hari baik individu maupun sebagai pelajar, anggota keluarga dan masyarakat serta untuk pertimbangan dalam pengambilan keputusan [3].

W.S. Winkel [4] menyatakan bahwa yang dimaksud dengan bimbingan kelompok adalah merupakan salah satu pengalaman melalui pemben-tukan kelompok yang khas untuk keperluan layanan bimbingan. Namun, di samping kelompok atau group yang dibentuk dalam rangka pengelolaan kegiatan bimbingan, di sekolah juga beraneka kelompok lain yang juga dirancang untuk memberikan suatu pengalaman pendidikan, meskipun mungkin mempunyai sasaran lain daripada sasaran layanan bimbingan.

Berdasarkan uraian di atas dapat ditarik suatu pengertian bahwa yang dimaksud dengan bimbingan kelompok adalah merupakan layanan bimbingan yang memungkinkan sejumlah siswa bersama-sama memperoleh berbagai bahan dari nara sumber (terutama dari guru pembimbing) yang bermanfaat untuk kehidupan sehari-hari baik sebagai individu maupun sebagai pelajar, anggota keluarga dan masyarakat. Bahan yang dimaksud itu juga dapat dipergunakan sebagai acuan untuk mengambil keputusan. Lebih jauh dengan layanan bimbingan kelompok para siswa dapat diajak untuk bersamasama mengemukakan pendapat tentang sesuatu dan membicarakan topik-topik penting, pengembangan nilai-nilai dan mengem-bangkan langkah-langkah bersama untuk menangani permasalahan yang dibahas dalam kelompok. Dengan demikian selain dapat membuahkan saling hubungan yang baik diantara anggota kelompok, kemam-puan berkomunikasi antar individu, pemahaman berbagai situasi dan kondisi lingkungan, juga dapat mengembangkan sikap dan tindakan nyata untuk mencapai hal-hal yang diinginkan sebagai terungkap didalam kelompok. Dengan demikian bimbingan kelompok lebih merupakan suatu upaya bimbingan kepada individu-individu melalui kelompok atau memanfaatkan dinamika untuk mencapai tujuan-tujuan bimbingan dan konseling.

Bannet (1963) mengemukakan tujuan bimbingan kelompok sebagai berikut: a. Memberikan kesempatan pada siswa atau individu untuk belajar hal-hal penting yang berguna bagi pengarahan dirinya yang berkaitan dengan masalah pendidikan, pekerjaan dan sosial.

b. Memberikan layanan pengembangan melalui kegiatan kelompok

c. Untuk mencapai tujuan bimbingan secara lebih ekonomis dan efektif daripada melalui bimbingan individu

d. Untuk melengkapi layanan konseling individu secara lebih aktif. Dengan mempelajari masalah-masalah yang umum dialami oleh individu dengan meredakan atau menghilangkan hambatan-hambatan emosional melalui kegiatan kelompok, maka pemahaman terhadap individu akan lebih mudah.

Dalam melaksanakan bimbingan kelompok selalu digunakan asas sebagai berikut.

a. Asas kesukarelaan maksudnya setiap siswa yang mendapatkan layanan bimbingan kelompok harus dengan sukarela mau mengemukakan masalah atau topik yang akan dibahas dan teman yang lainnya dengan sukarela pula mau membantu memberikan pandangan atau pendapatnya sehubungan masalah atau topik yang disampaikan.

5. Asas keterbukaan maksudnya setiap siswa tidak boleh menutupi atau menyembunyikan masalah atau topik yang dimiliki. Demikian pula siswa yang membantu, tidak boleh berpura-pura tidak bisa mengemukakan pendapat, lebih-lebih bersifat pasif.

Asas kegiatan maksudnya setiap siswa harus aktif memberikan pandangannya terhadap maslah atau topik yang di-kemukakan oleh temannya.

Asas kerahasiaan maksudnya bahwa setiap peserta sanggup merahasiakan bila diantara peserta yang menyampaikan masalah pribadi, kemudian peserta tersebut menginginkan masalahnya tidak disampaikan kepada siapaun. Hal ini perlu agar peserta yang bermasalah tidak ragu-ragu menyampaikan. Namun dalam bimbingan dibahas lebih banyak topik atau masalah yang bersifat umum.

Langkah-langkah Bimbingan Kelompok terdiri dari beberapa langkah sebagai berikut.

a. Tahap pembentukan

Tahap pembentukan, yaitu tahapan untuk mermbentuk kerumunan se-jumlah individu menjadi satu kelompok yang siap mengembangkan dinamika kelompok dalam mencapai tujuan bersama.

b. Tahap peraliahan

Tahap peralihan, yaitu tahapan untuk mengalihkan kegiatan awal kelompok ke kegiatan berikutnya yang lebih ter-arah pada pencapaian tujuan kelompok

c. Tahap Kegiatan

Tahap kegiatan, yiatu tahapan "kegiatan inti" untuk membahas topik-topik tertentu atau mengentaskan masalah pribadi anggota kelompok.

d. Tahap penyimpulan

Tahap penyimpulan, yaitu tahapan kegiatan untuk melihat kembali apa yang sudah dilakukan dam dicapai oleh kelompok. Peserta kelompok diminta melakukan refleksi berkenaan dengan kegiatan pembahasan yang baru saja mereka ikuti. 
e. Tahap penutupan

Tahap penutupan, yaitu merupakan tahap akhir dari seluruh kegiatan. Kelompok merencakan kegiatan selanjutnya, dan salam hangt perpisahan.

Berdasarkan uraian tersebut di atas, maka dapat dirumuskan permasalahan sebagai berikut. Apakah melalui layanan bimbingan kelompok dapat meningkatkan ketaatan peserta didik terhadap tata tertib sekolah pada siswa kelas IX SMP Negeri 1 Rogojampi, Banyuwangi, semester 1, tahun pelajaran 2015/2016.

Secara umum penelitian ini bertujuan untuk : (1) mengetahui dapat tidaknya layanan bimbingan kelompok meningkatkan ketaatan peserta didik terhadap tata tertib sekolah, dan (2) meningkatkan disiplin peserta didik terhadap tata tertib sekolah. Hipotesis tindakan yang dapat diajukan sesuai dengan judul di atas adalah sebagai berikut: Bimbingan kelom-pok dapat meningkatkan ketaatan peserta didik terhadap tata tertib sekolah pada siswa kelas IX SMP Negeri 1 Rogojampi, Banyuwangi, semester 1, tahun pelajaran 2015/2016.

\section{Metode Penelitian}

Sesuai dengan masalah yang akan dipecahkan dan tujuan yang ingin dicapai, penelitian ini menggunakan pendekatan deskriptif-kualitatif. Pendekatan ini digunakan agar dapat menggambarkan latar dan interaksi yang kompleks secara alamiah dari siswa sebagai sumber data penelitian. Mengenai jenis peneli-tian yang digunakan adalah penelitian tindakan partisipan, karena peneliti terlibat langsung dalam proses penelitian dari awal sampai berakhirnya penelitian. Penelitian ini melibatkan guru sebagai praktisi, sehingga dalam memecahkan permasalahan terjadi kolaborasi antara guru (praktisi) dan peneliti.

Jenis penelitian ini tergolong peneliti-an tindakan - Action Research). Penelitian tindakan Bimbingan dan Konseling (PTBK) adalah penelitian yang dilakukan oleh guru pembimbing di dalam kelas yang menjadi siswa asuhnya sendiri melalui refleksi diri, dengan tujuan untuk memperbaiki kenerja sebagai guru sehingga hasil belajar siswa menjadi lebih meningkat [5]. Menurut Arikunto [6] memberikan pengertian bahwa penelitian tindakan kelas merupakan suatu pencermatan ter-hadap kegiatan belajar berupa sebuah tindakan, yang sengaja dimunculkan dan terjadi dalam sebuah kelas secara bersama.

Berdasarkan kedua pendapat tersebut di atas dapat ditarik suatu pengertian bahwa yang dimaksud dengan penelitian tindakan adalah merupakan suatu tindak-an perbaikan yang dilakukan guru pem-bimbing untuk memperbaiki tugastugas dan kondisi bimbingan dan konseling. Subjek penelitian ini adalah siswa kelas IX SMP Negeri 1 Rogojampi, Tahun Pelajaran 2015/2016 yang melakukan pelanggaran terhadap tata tertib sekolah pada bidang pakaian seragam, kehadiran di sekolah, dan pembayaran Sumbangan Komite Sekolah.

Dalam penelitian ini, siswa menjadi sumber utama dalam perolehan data berkaitan dengan pelanggaran terhadap tata tertib sekolah pada bidang pakaian seragam, kehadiran di sekolah, dan pembayaran Sumbangan Komite Sekolah pada siswa kelas IX SMP Negeri 1 Rogojampi. Alasan mengapa penelitian ini dilaksanakan dikelas IX atau dijadikan subjek penelitian karena adanya permasalahan-permasalahan diantaranya: pelanggaran terhadap tata tertib sekolah pada bidang pakaian seragam, kehadiran di sekolah, dan pembayaran Sumbangan Komite Sekolah masih cukup tinggi.

Mengacu pada batasan dari penelitian ini, maka objek penelitian ini adalah pelanggaran siswa terhadap tata tertib sekolah pada bidang pakaian seragam, kehadiran di sekolah, dan pembayaran Sumbangan Komite Sekolah melalui bimbingan kelompok. Rancangan penelitian tindakan bimbingan dan konseling (PTBK) ini diambil menurut Kemmis dan McTaggrat [7]. Yang memberikan batasan pelaksanaan, yakni : (1). Tahap Perencanaan, (2).Tahap Tindakan, (3).Tahap Observasi/ Evaluasi, (4).Tahap Terakhir adalah Refleksi.

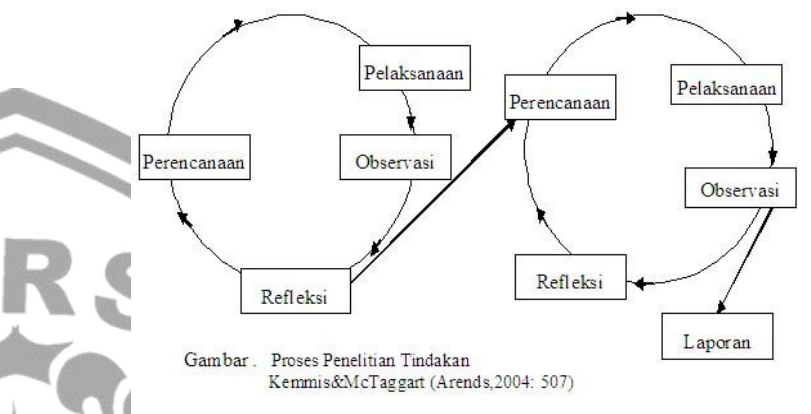

1. Merencanakan Tindakan

Di dalam memberikan tindakan, peserta didik yang melakukan pelang-garan tata tertib akan dikelompokkan sesuai dengan jenis pelanggaran yang dilakukan, kemudian diberikan bimbingan kelompok dengan topik-topik yang sesuai dengan masing-masing pelanggaran tersebut.

2. Melaksanakan tindakan

Setelah kelompok terbentuk sesuai dengan jenis pelanggaran yang dilaku-kan maka selanjutnya diberikan bim-bingan kelompok sesuai dengan tahapan-tahapan bimbingan kelompok seperti yang telah diuraikan di atas.

3. Prosedur Observasi

Untuk memperoleh data mengenai perubahan ketaatan terhadap tata tertib sekolah, setelah diberikan tindak-an, perlu diadakan observasi terhadap prilaku peserta didik, prosedur obser-vasi yang ditempuh adalah dengan mengadakan kerjasama dengan wali kelas, guru piket dan guru-guru lain-nya, agar data yang diperoleh lebih akurat.

4. Refleksi

Setelah diadakan observasi dan hasil observasi itu dievaluasi, kemudian jika tindakan belum memperoleh hasil yang maksimal, maka perlu dipikirkan cara-cara atau alternatif-alternatif lain yang kira-kira memungkinkan untuk dapat meningkatkan ketaatan peserta didik terhadap tata tertib sekolah.

Teknik analisis yang digunakan untuk mengolah data di atas adalah: Analisis Varians (Anava) dengan rumus sebagai berikut :

$$
\begin{aligned}
& F=\frac{R K_{A}}{R K_{D}} \quad R K_{A}=\frac{J K_{A}}{d b_{A}} \quad R K_{D}=\frac{J K_{D}}{d b_{D}} \\
& J K_{A}=\frac{\left(\sum X_{A}\right)^{2}}{n_{A}} \frac{\left(\sum X T\right)^{2}}{N}
\end{aligned}
$$




$$
J K_{D}=\sum X^{2} T-\frac{\left(\sum X_{A}\right)^{2}}{n_{A}}
$$

Keterangan :

$\mathrm{F}=$ Harga " $\mathrm{F}$ " dari Fisher

$\mathrm{RK}_{\mathrm{A}}=$ Rata-rata kuadrat antar cuplikan

$\mathrm{RK}_{\mathrm{D}}=$ Rata-rata kuadrat dalam cuplikan

$\mathrm{JK}_{\mathrm{A}}=$ Jumlah kuadrat antar cuplikan

$\mathrm{JK}_{\mathrm{D}}=$ Jumlah kuadrat dalam cuplikan

$\mathrm{db}_{\mathrm{A}}=$ Derajat kebebasan antar cuplikan

$\mathrm{db}_{\mathrm{D}}=$ Derajat kebebasan antar cuplikan

$\mathrm{n}_{\mathrm{A}} \quad=$ Jumlah sampel tiap katagori

$\mathrm{a} \quad=$ Banyaknya kelompok

\begin{tabular}{|c|c|c|c|c|}
\hline 9 & Pur & IX I & $6 \mathrm{x}$ & $2,00 \mathrm{x}$ \\
\hline 10 & Res & IX I & $5 \mathrm{x}$ & $1,67 \mathrm{x}$ \\
\hline 11 & Edi & IX J & $4 \mathrm{x}$ & $1,33 \mathrm{x}$ \\
\hline
\end{tabular}

Tabel 3. Siswa yang melakukan pelanggaran pada bidang pakaian di sekolah (kelompok II)

\begin{tabular}{|c|c|c|c|c|}
\hline No & Kode Nama & Kelas & $\begin{array}{c}\text { Jumlah Pelangaran } \\
\text { dalam } 3 \text { bulan }\end{array}$ & $\begin{array}{c}\text { Rata-rata dalam 1 } \\
\text { bulan }\end{array}$ \\
\hline 1 & Per & IX A & $4 \times$ & $1,33 \times$ \\
\hline 2 & Adh & IX C & $4 \mathrm{x}$ & $1,33 \mathrm{x}$ \\
\hline 3 & Bud & IX C & $4 \mathrm{x}$ & $1,33 \mathrm{x}$ \\
\hline 4 & Yud & IX D & $6 \mathrm{x}$ & $2,00 \mathrm{x}$ \\
\hline 5 & Eri & IX E & $4 \mathrm{x}$ & $1,33 \mathrm{x}$ \\
\hline 6 & Dani & IX F & $6 \mathrm{x}$ & $2,00 \mathrm{x}$ \\
\hline 7 & Mir & IX G & $5 \mathrm{x}$ & $1,67 \mathrm{x}$ \\
\hline 8 & Agu & IX H & $4 \mathrm{x}$ & $1,33 \mathrm{x}$ \\
\hline 9 & Pur & IX I & $2 \mathrm{x}$ & $0,67 \mathrm{x}$ \\
\hline 10 & Res & IX I & $6 \mathrm{x}$ & $2,00 \mathrm{x}$ \\
\hline 11 & Dedi & IX J & $4 \mathrm{x}$ & $1,33 \mathrm{x}$ \\
\hline
\end{tabular}

\section{Hasil Penelitian}

\section{A. Penyajian Hasil Penelitian}

\section{Subjek Penelitian}

Berdasarkan data pada buku pencatatan pelanggaran tata tertib sekolah yang dilakukan oleh siswa kelas IX SMP Negeri 1 Rogojampi, semester 1, Tahun Pelajaran 2015/2016 yang dikutip dari tanggal 21 Juli sampai dengan 21 September 2015 (selama 3 bulan) dapat disajikan seperti pada tabel di bawah ini.

Tabel 1. Daftar Nama Siswa Kelas IX SMP Negeri 1 Rogojampi,Banyuwangi, Semester 1, Tahun Pelajaran 2015/2016 yang Melakukan Pelanggaran Terhadap Tata Tertib Sekolah

\begin{tabular}{|c|c|c|c|c|c|}
\hline \multirow{2}{*}{ No } & \multirow{2}{*}{ Kode Nama } & \multirow{2}{*}{ Kelas } & \multicolumn{3}{|c|}{ Jenis Pelanggaran } \\
\cline { 4 - 6 } & & & Hadir & Pakaian & Iuran \\
\hline 1 & Per & IX A & - & $4 \times$ & $3 \times$ \\
\hline 2 & Ari & IX B & $4 \times$ & - & $3 \times$ \\
\hline 3 & Adh & IX C & - & $4 \times$ & - \\
\hline 4 & Bud & IX C & $6 \times$ & $4 \times$ & $3 \times$ \\
\hline 5 & Wis & IX D & $5 \times$ & - & $3 \times$ \\
\hline 6 & Yud & IX D & $4 \times$ & $6 \times$ & - \\
\hline 7 & Dwi & IX E & $4 \times$ & - & $3 \times$ \\
\hline 8 & Edi & IX E & $5 \times$ & - & $3 \times$ \\
\hline 9 & Eri & IX E & $4 \times$ & $4 \times$ & - \\
\hline 10 & Dan & IX F & - & $6 \times$ & $3 \times$ \\
\hline 11 & Mir & IX G & $6 \times$ & $5 \times$ & - \\
\hline 12 & Agu & IX H & $6 \times$ & $4 \times$ & $3 \times$ \\
\hline 13 & Pur & IX I & $5 \times$ & $4 \times$ & - \\
\hline 14 & Res & IX I & - & $2 \times$ & $3 \times$ \\
\hline 15 & Ded & IX J & $4 \times$ & $6 \times$ & - \\
\hline 16 & Sap & IX J & - & $4 \times$ & - \\
\hline
\end{tabular}

Tabel 4. Siswa yang melakukan pelanggaran pada bidang iuran bulanan komite sekolah (kelompok III)

\begin{tabular}{|c|c|c|c|c|}
\hline No & Kode Nama & Kelas & $\begin{array}{c}\text { Jumlah Pelangaran } \\
\text { dalam 3 bulan }\end{array}$ & $\begin{array}{c}\text { Rata-rata dalam 1 } \\
\text { bulan }\end{array}$ \\
\hline 1 & Per & IX A & $3 \times$ & $1 \times$ \\
\hline 2 & Ari & IX B & $3 \times$ & $1 \times$ \\
\hline 3 & Bud & IX C & $3 \times$ & $1 \times$ \\
\hline 4 & Wis & IX D & $3 \times$ & $1 \times$ \\
\hline 5 & Dwi & IX E & $3 \times$ & $1 \times$ \\
\hline 6 & Edi & IX E & $3 \times$ & $1 \times$ \\
\hline 7 & Dan & IX F & $3 \times$ & $1 \times$ \\
\hline 8 & Agu & IX H & $3 \times$ & $1 \times$ \\
\hline 9 & Res & IX I & $3 \times$ & \\
\hline
\end{tabular}

\section{Pelaksanaan Tindakan ke 1 (satu)}

Dalam pelaksanaan tindakan ke 1 (satu), tahapan kegiatan yang dilakukan adalah sebagai berikut :

a. Babak pendahuluan

1). Mengajak siswa berdoa bersama menurut kepercayaan masing-masing, untuk menenangkan pikiran serta mohon kepada Tuhan Yang Maha Esa agar kegiatan yang dilakukan mencapai hasil maksimal.

2). Para siswa diberi penjelasan mengenai pengertian bimbingan kelompok termasuk pengertian mengenai dinamika kelompok

3). Para siswa diberi penjelasan tentang tujuan yang ingin dicapai melalui bimbingan kelompok

4). Menjelaskan kepada siswa asas-asas yang dipergunakan dalam bimbingan kelompok

b. Babak Pelaksanaan

Untuk memudahkan di dalam melaksanakan bimbingan kelompok, maka dibentuk kelompok permanen sesuai dengan pelanggaran yang dilakukan oleh siswa. Kelompok yang dimaksud adalah sebagai berikut.

Tabel 2. Siswa yang melakukan pelanggaran pada bidang kehadiran di sekolah (kelompok 1)

\begin{tabular}{|c|c|c|c|c|}
\hline No & Kode Nama & Kelas & $\begin{array}{c}\text { Jumlah Pelangaran } \\
\text { dalam 3 bulan }\end{array}$ & $\begin{array}{c}\text { Rata-rata dalam 1 } \\
\text { bulan }\end{array}$ \\
\hline 1 & Ari & IX B & $4 \times$ & $1,33 \times$ \\
\hline 2 & Bud & IX C & $6 \times$ & $2,00 \times$ \\
\hline 3 & Wis & IX D & $5 \times$ & $1,67 \times$ \\
\hline 4 & Yud & IX D & $4 \times$ & $1,33 \times$ \\
\hline 5 & Dwi & IX E & $4 \times$ & $1,67 \times$ \\
\hline 6 & Edi & IX E & $5 \times$ & $1,33 \times$ \\
\hline 7 & Mir & IX G & $4 \times$ & $2,00 \times$ \\
\hline 8 & Agu & IX H & $6 \times$ & \\
\hline
\end{tabular}

1). Masing-masing siswa disuruh memperkenalkan diri dengan menyebut identitas diri secara lengkap serta kegemaran atau hobi masing-masing

2). Siswa diajak bermain untuk men-jalin keakraban sehingga dinamika kelompok hidup dan berkembang

3). Siswa diajak membahas topik per-masalahan yang telah disiapkan siswa agar berperan secara aktif sehingga hasil yang diperoleh dapat secara maksimal

4). Pembimbing menyimpulkan hasil pembahasan yang dilakukan siswa

c. Babak Akhir

1). Siswa diajak berdoa bersama kembali untuk mengakhiri kegiatan

2). Untuk tetap menjaga keakraban antar sesama anggota kelompok, siswa diajak saling berjabatan 
tangan atau nyanyi bersama dan selanjutnya siswa dibubarkan.

Setelah tindakan ke 1 (satu) ini dilaksanakan selanjutnya dilakukan obser-vasi dengan prosedur seperti tersebut di atas, untuk mengetahui ada tidaknya perubahan ketaatan siswa terhadap tata tertib sekolah.

\section{Hasil Tindakan ke 1 (satu)}

Tabel 5. Jumlah Pelanggaran Sebelum dan Sesudah Tindakan ke 1 (Satu)

\begin{tabular}{|c|c|c|c|c|}
\hline \multirow[t]{3}{*}{ No } & \multirow[t]{2}{*}{ Kode Siswa } & \multirow[t]{2}{*}{ Kelas } & $\begin{array}{c}\text { Sesudah tindakan } \\
\text { ke } 1\end{array}$ & $\begin{array}{c}\text { Sesudah tindakan } \\
\text { ke } 2\end{array}$ \\
\hline & & & $\begin{array}{c}\text { Jumlah } \\
\text { pelanggaran }\end{array}$ & $\begin{array}{c}\text { Jumlah } \\
\text { pelanggaran }\end{array}$ \\
\hline & \multicolumn{2}{|c|}{ KELOMPOK 1} & & \\
\hline 1 & Ari & IX B & $0 \mathrm{x}$ & $0 \mathrm{x}$ \\
\hline 2 & Bud & IX C & $1 \mathrm{x}$ & $0 \mathrm{x}$ \\
\hline 3 & Wis & IX D & $1 \mathrm{x}$ & $0 \mathrm{x}$ \\
\hline 4 & Yud & IX D & $0 \mathrm{x}$ & $0 \mathrm{x}$ \\
\hline 5 & Dwi & IX E & $0 \mathrm{x}$ & $0 \mathrm{x}$ \\
\hline 6 & Edi & IX E & $1 \mathrm{x}$ & $0 \mathrm{x}$ \\
\hline 7 & Mir & IX G & $0 \mathrm{x}$ & $0 x$ \\
\hline 8 & Agu & IX H & $2 x$ & $0 \mathrm{x}$ \\
\hline 9 & Pur & IX I & $1 \mathrm{x}$ & $0 x$ \\
\hline 10 & Res & IX I & $1 \mathrm{x}$ & $0 \mathrm{x}$ \\
\hline \multirow[t]{2}{*}{11} & Edi & IX J & $0 x$ & $0 \mathrm{x}$ \\
\hline & \multicolumn{2}{|c|}{ KELOMPOK II } & & \\
\hline 1 & Per & IX A & 0 & $0 x$ \\
\hline 2 & Adh & IX C & $0 x$ & $0 x$ \\
\hline 3 & Bud & IX C & $0 \mathrm{x}$ & $0 x$ \\
\hline 4 & Yud & IX D & $1 \times$ & $0 x$ \\
\hline 5 & Eri & IX E & $0 \mathrm{x}$ & $0 x$ \\
\hline 6 & Dan & IX F & $1 x$ & $0 x$ \\
\hline 7 & Mir & IX G & $1 \mathrm{x}$ & $0 \mathrm{x}$ \\
\hline 8 & Agu & IX H & $0 \mathrm{x}$ & $0 x$ \\
\hline 9 & Pur & IX I & $0 \mathrm{x}$ & $0 \mathrm{x}$ \\
\hline 10 & Res & IX I & $0 \mathrm{x}$ & $0 \mathrm{x}$ \\
\hline 11 & Ded & IX J & $2 x$ & $0 x$ \\
\hline \multirow[t]{2}{*}{12} & Edi & IX J & $0 \mathrm{x}$ & $0 x$ \\
\hline & \multicolumn{2}{|c|}{ KELOMPOK III } & & \\
\hline 1 & Per & IX A & $0 \mathrm{x}$ & $0 x$ \\
\hline 2 & Ari & IX B & $0 \mathrm{x}$ & $0 x$ \\
\hline 3 & Bud & IX C & $1 \mathrm{x}$ & $1 \mathrm{x}$ \\
\hline 4 & Wis & IX D & $1 \mathrm{x}$ & $0 x$ \\
\hline 5 & Dwi & IX E & $1 \mathrm{x}$ & $0 \mathrm{x}$ \\
\hline 6 & Edi & IX E & $0 x$ & $0 \mathrm{x}$ \\
\hline 7 & Dan & IX F & $0 x$ & $0 x$ \\
\hline 8 & Agu & IX H & $1 \mathrm{x}$ & $0 x$ \\
\hline 9 & Res & IX I & $0 x$ & $0 x$ \\
\hline
\end{tabular}

B. Pembahasan dan Analisis Seluruh Hasil Tindakan

Berdasarkan hasil tindakan seperti tersebut diatas, ternyata sampai tindakan ke 2 (dua) masih ada 1 (satu) orang siswa yang belum tuntas dalam artian masih melakukan pelanggaran tata tertib sekolah pada bidang pembayaran iuran bulanan. Setelah diadakan pendekatan dengan siswa tersebut, ternyata penyebab pelanggaran tersebut adalah keterlambatan pengiriman uang dari orang tua mereka karena orang tua mereka berada di Lampung Sumatra.

Teknik analisis yang digunakan untuk mengolah data di atas adalah Analisis Varians (Anava) dengan Kaidah pengujian Hipotesisis :

Tolak Ho jika Fo $>$ F tabel

Terima Ho jika Fo $<$ F tabel

\section{Langkah-langkah analisisnya sebagai berikut :}

\section{A. Merumuskan Ho}

Hipotesis nol (Ho) yang diajukan adalah sebagai berikut : Bimbingan kelompok tidak dapat meningkatkan ketaatan siswa terhadap tata tertib sekolah pada siswa kelas IX SMP
Negeri 1 Rogojampi, Banyuwangi, tahun pelajaran 2015/2016.

B. Menyusun Daftar Belanja Statistik

Tabel 7. Daftar Belanja Statistik untuk Analisis Varians

\begin{tabular}{|c|c|c|c|c|}
\hline Statistik & $\mathrm{A} 1$ & $\mathrm{~A} 2$ & $\mathrm{~A} 3$ & Total \\
\hline $\mathrm{n}$ & 32 & 32 & 32 & 96 \\
\hline$\sum X$ & 44,31 & 16 & 1 & 61,31 \\
\hline$\sum X^{2}$ & 65,85 & 20 & 1 & 86,85 \\
\hline $\mathrm{X}$ & 1,38 & 0,5 & 0,03 & 1,91 \\
\hline
\end{tabular}

\section{Memasukkan Data ke dalam Rumus}

$$
\begin{aligned}
& J K_{A}=\frac{\left(\sum X_{A}\right)^{2}}{n_{A}}-\frac{\left(\sum X T\right)^{2}}{N} \\
& J K_{A}=\frac{\left(\sum X_{A 1}\right)^{2}}{n_{A 1}}+\frac{\left(\sum X_{A 2}\right)^{2}}{n_{A 2}}+\frac{\left(\sum X_{A 3}\right)^{2}}{n_{A 3}}-\frac{\left(\sum X T\right)^{2}}{N}
\end{aligned}
$$$$
J K_{A}=30,23
$$$$
J K_{D}=\sum X^{2} T-\frac{\left(\sum X_{A}\right)^{2}}{n_{A}}
$$$$
J K_{D}=17,45
$$$$
d b_{A}=a-1=2 \quad d b_{D}=N-a=93
$$
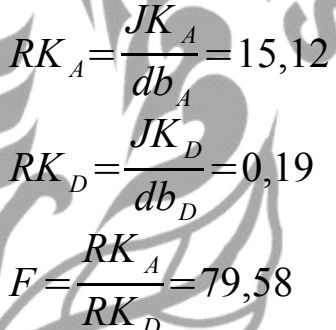

\section{Menguji Nilai $\mathbf{F}$}

Berdasarkan db a - 1 lawan $\mathrm{N}-\mathrm{a}=2$ lawan 93 dan taraf signifikansi $5 \%$ batas penolakan nilai-nilai $\mathrm{F}$ dalam tabel adalah 3.09 ini berarti Fo > Ft. Dengan demikian Ho ditolak. Karena harga Fo signifikan, maka harus dilanjutkan dengan ujit Scheffe dengan rumus sebagai berikut :

$$
\begin{aligned}
& r_{1-2}=\frac{X_{1}-X_{2}}{\sqrt{2 \mathrm{RK}_{D} / n}}=8,92 \\
& r_{1-3}=\frac{X_{1}-X_{3}}{\sqrt{2 \mathrm{RK}_{D} / n}}=13,50 \\
& r_{2-3}=\frac{X_{2}-X_{3}}{\sqrt{2 \mathrm{RK}_{D} / n}}=4,70
\end{aligned}
$$

\section{Menguji nilai $t$}

Berdasarkan $d b\left(n_{1}+n_{2}-2\right)=62$, dengan taraf signifikansi $5 \%$ batas penolakan nilai t pada tabel adalah 2.00 , ini berarti to $>t_{t}$. Dengan demikian Ho ditolak.

\section{E. Menarik Kesimpulan}

Berdasarkan hasil perhitungan nilai $\mathrm{F}$ dan uji $\mathrm{t}$ Scheffe menunjukkan signifikan, yang berarti Ho ditolak, maka dengan demikian dapat ditarik kesimpulan sebagai berikut: Bimbingan Kelompok dapat meningkatkan Ketaatan Siswa 
terhadap Tata Tertib Sekolah pada Siswa Kelas IX SMP Negeri 1 Rogojampi, Semester 1, Tahun Pelajaran 2015/ 2016.

\section{Kesimpulan dan Saran}

\section{A. Kesimpulan}

Berdasarkan hasil penelitian yang telah dikemukakan seperti tersebut diatas, maka dapat disimpulkan sebagai berikut :

1. Layanan Bimbingan kelompok dapat meningkatkan ketaatan siswa terhadap tata tertib sekolah.

2. Layanan Bimbingan kelompok dapat meningkatkan disiplin siswa.

\section{B. Saran-saran}

Berdasarkan kenyataan di lapangan bahwa masih banyak siswa yang me-lakukan pelanggaran terhadap tata tertib sekolah, maka untuk selanjutnya kami sarankan sebagai berikut :

1. Kepada Wali Kelas, guru mata pe-lajaran, guru pembimbing dan staf sekolah lainnya apabila menemukan siswa yang melakukan pelanggaran terhadap tata tertib sekolah hendaknya sedini mungkin menanganinya dengan cara memberikan layanan bimbingan kelompok karena bimbingan kelompok merupakan salah satu cara yang sudah terbukti dapat meningkatkan ketaatan siswa terhadap tata tertib sekolah.

2. Kepada wali kelas, guru mata pelajaran dan staf sekolah lainnya yang belum paham tentang melaksanakan bimbingan kelompok, hendaknya selalu mengadakan koordinasi dengan guru pembimbing yang ada di sekolah tersebut.

\section{Daftar Pustaka}

[1] Badudu, J.S dan Sultan Mohammad Zain, 1996. Kamus Umum Bahasa Indonesia. Cetakan ke-2. Jakarta : Pustaka Sinar harapan

[2] Direktorat Jenderal Pendidikan Dasar dan Menengah Depdikbud, 1998. Pedoman Pelaksanaan Penye-lenggaraan Pendidikan dan Pengajaran Tahun Ajaran 1978. Jakarta CV. Surya Dana

[3] Sukardi, 1988. Bimbingan dan Penyuluhan Belajar di Sekolah. Surabaya. Usaha Nasional.

[4] Setiawati Ni Ketut. 1997. Layanan Bimbingan Kelompok Makalah, Disajikan dalam pelatihanGuru Bimbingan Sekolah Lanjutan Pertama Propinsi Bali, 1997

[5] Wardhani dkk. 2007. Penelitian Tindakan Kelas. Jakarta : Universitas Terbuka.

[6] Suharsimi Arikunto 2007. Penelitian Tindakan Kelas. Jakarta : Bumi Aksara.

[7] Suranto, dll. 1997. Pedoman pelaksanaan Penelitian Tindakan kelas. Jakarta Direktorat Pendidikan Tinggi, Depdikbud. 